Hall, J. F., and Polte, J. W. (1956). F. appl. Physiol., 8, 539.

Horvath, S. M., Radcliffe, C. E., Hutt, B. K., and Spurr, G. B. (1955). Ibid., 8,145 .

Hutchins, L. W., and Scharf, M. (1947). Sears Fdn 9. mar. Res., 6, No. 3 .

Keatinge, WV. R. (1959). The effect of work, clothing, and adaptation on the maintenance of the body temperature in the water and on reflex responses to immersion. Ph.D. Thesis, University of Cambridge.

(1960). 7. Physiol. (Lond.), 153, 166

- (1960). f. Physiol. (Lond.), 153, 166.
Lee, E. C. B. (1965). Survival át Sea. Estratto da Atti del Centro di studi $e$ ricerche per l'assistenza sanitaria e sociale dei marittimi. C.I.R.M., Rome.

McCance, R. A., Ungley, C. C., Crosfill, J. W. L., and Widdowson, E. M. (1956). Spec. Rep. Ser. med. Res. Coun. (Lond.), No. 291.

Molnar, G. W. (1946). Ұ. Amer. med. Ass., 131, 1046.

Pugh, L. G. C., and Edholm, O. G. (1955). Lancet, 2, 761.

Ungley, C. C. (1948). Roy. nav. med. Bull., 26, 45. Cited by F. P. Ellis in Personnel Research in the Royal Navy 1939-1945. Medical Research Council R.N.P. $50 / 580$ (1950).

\title{
Development of Jet Injection and its Application to Intralesional Therapy in Dermatology
}

\author{
E. J. MOYNAHAN,* F.R.C.P. ; A. BOWYER,* B.M., B.CH., M.R.C.P.
}

Brit. med. F., 1965, 2, 1541-1543

Injection with needle and syringe has a number of disadvantages : it is nearly always painful and may be frightening to children ; one cannot be certain of the volume of material that is actually injected ; and the whole procedure takes a considerable amount of time.

It is not surprising that alternative techniques have been sought. The most suitable method which has been developed seems to be the use of high-pressure jet injectors, which throw the material to be injected with considerable force through a very fine nozzle. The emergent column of liquid or jet has a very narrow diameter, and its high velocity enables it to penetrate the skin and deeper tissues with ease. The injection is invariably pain-free, the patient experiencing only a fine "flick" sensation at the injection site.

Several instruments have been developed and used for treatment in many conditions other than purely dermatological diseases. The Hypospray (Hingson and Figge, 1952) is probably the most widely studied of such instruments. This employs single-dose Metapules containing up to $1 \mathrm{ml}$. of solution, and has been used for the administration of antibiotics (Hirsh et al., 1948), immunization (Hughes et al., 1949), the treatment of diabetes (Perkin et al., 1950), and rheumatoid arthritis (by intraarticular injection) (Ziff et al., 1956), and finally for dental anaesthesia (Margetis et al., 1958).

A more recent development is the small dose Dermojet developed by Krantz (Krantz, 1960). This places a small fixed volume of approximately $0.04 \mathrm{ml}$. of solution into the skin and is used mainly for local anaesthesia. Krantz also suggested its use in intradermal local therapy as well as vaccination. The instrument is semi-automatic and can deliver up to 30 injections a minute.

The instruments mentioned above and other experimental models can deliver only a single dose, from sterile sealed ampoules, as in the Hypospray, or from a small reservoir, as in the Dermojet. A considerable advance was made with the development of multiple-dose instruments-for example, the Presso-Jet (Warren et al., 1955) and the Hypospray Multidose Jet Injector (Towle, 1960).

These instruments were designed to deal with the problem of large-scale protection of populations exposed to smallpox and cholera during epidemics and at times of disaster, such as floods or earthquakes, when rapid techniques are urgently required. These injectors are similar in principle to the singledose instrument, but instead of being " hand-cocked" they are

\footnotetext{
* Department of Dermatology, Guy's Hospital.
}

loałcd by hydraulic systems driven by an electric motor, and were used with considerable success in mass inoculation campaigns in America (Warren et al., 1955) and East Pakistan (Towle, 1960).

A more recent development is the dental jet injector (Stephens and Kramer, 1964), which employs a reciprocating piston connected to the compressed-air source of the dental table. This instrument is more flexible than those mentioned above. Both the pressure, and hence the depth of the injection, and the volume of the injection are variable between wide limits. It appears to be very effective, particularly for dental anaesthesia.

Apart from the speed and the absence of pain, these instruments do not resemble conventional needles and syringes, and

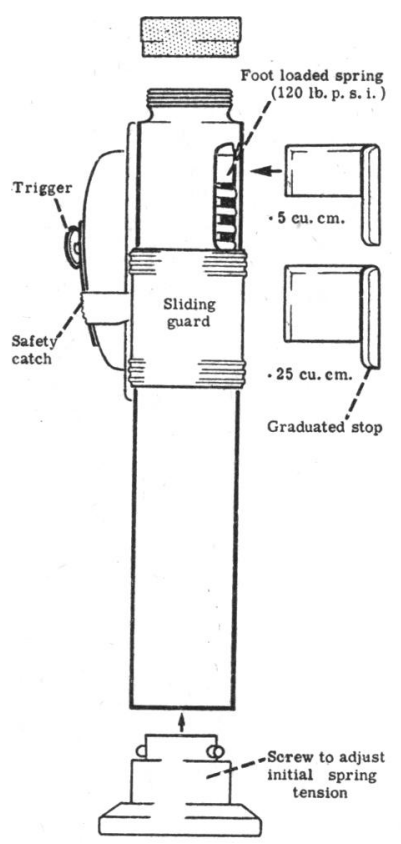

FIG. 1

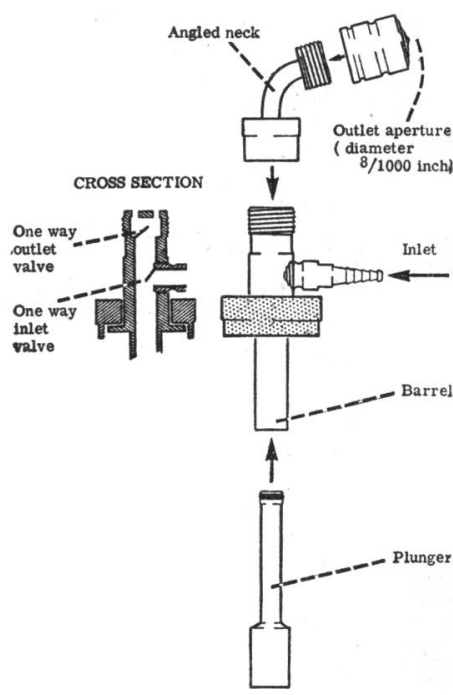

FIG. 2
FIg. 1.-The Porton Needleless Injector. The syringe (Fig. 2) when assembled is screwed into the top of the syringe handle. Dose is determined by the graduated stops which arrest the travel of the piston in the handle. Depth of iniection is controlled by adiusting the initial tension on the spring with the screw. The foot-operated priming mechanism is not illustrated here. FIG. 2-Syringe components of the Porton not iluster. assembled. The inlet valve is connected to a reservoir containing the material to be injected. 
therefore fear of a known painful process is absent. This is of cardinal importance in paediatric cases. Once sterilized and assembled, the instruments remain sterile. Resterilization is unnecessary, in contrast to needle and syringe methods. The only limiting factor is the speed with which the instrument can be reloaded.

At about the time that the Presso-Jet and Hypospray multiple jet instruments were being developed the Microbiological Research Establishment at Porton, Wiltshire, England, was asked to produce a jet injector that could be used in times of disaster. A team developed an instrument (Fig. 1) which has been called the Porton needleless injector. It is spring-loaded and the cocking mechanism is operated by a foot pedal. The fluid to be injected is held in a reservoir and is connected to the interior of the syringe by one-way valve systems (Fig. 2). By arresting the travel of the piston by means of different-sized stops doses of $1 \mathrm{ml}$. or less can be given; and by adjusting the initial tension on the spring control may be obtained over the depth to which the injected material penetrates the tissues (Fig. 3). The instrument can give up to 30 injections per minute.

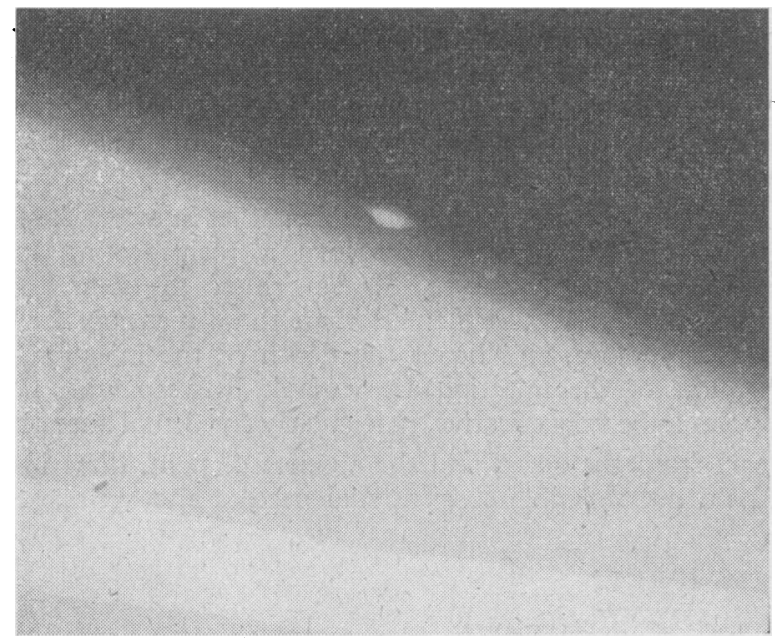

FIG. 3.-Radiograph of left forearm showing $0.1 \mathrm{ml}$. of radioopaque material deposited in the skin.

The control of the speed, the volume injected, and the depth of injection gives considerable advantages over other multidose instruments. The other outstanding features in its design are the ease with which it can be loaded and the simplicity of the priming system-a foot-operated lever in contradistinction to the hydraulic systems powered by electrical motor of other instruments.

\section{Present Study}

There is increasing evidence that intralesional steroids, given by needle and syringe, are of value in a wide variety of dermatological conditions. Successful therapy has been reported in alopecia areata (Orentreich et al., 1960 ; Gombiner and Malkinson, 1961), psoriasis (Gerard, 1960 ; Readett, 1961 ; Weidman, 1963), discoid lupus erythematosus (Rowell, 1962; Ferguson Smith, 1962), and in many other conditions, including lichen planus, lichen simplex chronicus, granuloma annulare, sarcoidosis, and pretibial myxoedema (James, 1960, 1961 ; Rebello, 1962).

The steroid most commonly used is triamcinolone acetonide in a concentration of $10 \mathrm{mg} . / \mathrm{ml}$., and the injections are usually given through fine needles of about 25 gauge from Mantoux syringes. Up to $0.2 \mathrm{ml}$. of the suspension is injected into the lesion, and the injections are repeated at distances of 5 to $10 \mathrm{~mm}$. from the first site. Alternatively, the entire lesion may be infiltrated through one puncture site by directing the needle parallel to the skin surface.

For some time one of us (A. B.) has considered the use of a jet injector in dermatological therapy. Apart from the work of Krantz (1960), the only other studies of jet therapy in dermatology had been those of Larrick and Thompson (1949) and Preston et al. (1951). These reports described principally the use of procaine for local anaesthesia and the treatment of lichen simplex chronicus with the Hypospray.

It is difficult to obtain such an instrument. After a number of inquiries A. B. saw the Porton needleless injector in October 1962 , and it became immediately apparent that this instrument would be admirably suited to intralesional therapy. A modified injector was built at Porton and handed over for clinical trial late in December 1962.

Since that time a total of 125 patients have been treated at Guy's Hospital, and a grand total of 16,000 individual injections have been given. The diseases treated include alopecia areata, totalis, and universalis, psoriasis, pustular psoriasis, chronic discoid lupus erythematosus, and granuloma annulare. Some of the results are given in the Table. A fuller account of these results will be published later.

Results of Intralesional Therapy by fet Injection in 83 Patients

\begin{tabular}{|c|c|c|c|}
\hline \multirow{2}{*}{ Disease } & \multicolumn{2}{|c|}{ No. of Patients } & \multirow{2}{*}{ Response } \\
\hline & Child & Adult & \\
\hline $\begin{array}{l}\text { Alopecia areata } \quad \ldots \\
\text { Psoriasis } \ldots \\
\text { Pustular psoriasis } \\
\text { Discoid L.E. } \\
\text { Granuloma annulare }\end{array}$ & $\frac{21}{\bar{Z}}$ & $\begin{array}{r}39 \\
8 \\
7 \\
4 \\
-\end{array}$ & $\begin{array}{l}\text { Regrowth in all except } 1 \text { adult } \\
6 \text { gond ( } 2 \text { relapsed), } 2 \text { poor } \\
5 \text { good (1 relapsed), } 2 \text { poor } \\
\text { Cleared. } 2 \text { needed further injections } \\
\text { All cleared }\end{array}$ \\
\hline
\end{tabular}

Many of the patients with alopecia areata had had treatment by needle and syringe, and all of them preferred the jet technique. As we have pointed out, this freedom from pain was of immense value in our child patients, as the instrument in no way resembled a needle and syringe, and there was no fear despite previous experience of the conventional method. This was well illustrated by a 9-year-old girl who had attended another hospital for alopecia areata. She had been admitted there and given a general anaesthetic, so that conventional injections could be made. Using the Porton needleless injector this child has had a total of 107 separate injections in the out-patient department on five attendances. She sat happily in the chair and experienced no pain or discomfort.

\section{Materials and Methods}

The volume of injection given at each puncture is $0.1 \mathrm{ml}$., and the largest number of injections at any one time is 60 . The usual number of injections varies between 20 and 30. All the patients are treated at weekly intervals and the maximum number of treatments to any one area is three. The steroid used in all the treatments is triamcinolone acetonide. This is supplied in a strength of $10 \mathrm{mg} . / \mathrm{ml}$. and is diluted by half to give a final concentration of $5 \mathrm{mg} . / \mathrm{ml}$.

It is possible to infiltrate an area of $30 \mathrm{sq} . \mathrm{cm}$. with 30 injections, using a total volume of $3 \mathrm{ml}$. of solution. The total average dosage given at any one treatment is $15 \mathrm{mg}$., with a maximum of $30 \mathrm{mg}$. The dosage normally employed for intradermal therapy with triamcinolone acetonide is $10 \mathrm{mg} . / \mathrm{ml}$., and total doses of 10,20 , or $30 \mathrm{mg}$. may be given at any one treatment (B.M.f., 1963). The total dosage with the Porton Needleless Injector is therefore, well within the usual range of dosage employed by other workers. 


\section{Complications}

The undesirable side-effects reported with intralesional therapy have been discussed by Goldman (1962). The commonest is a pseudo-atrophy at the site of injection, and Orentreich et al. (1960) reported an incidence of up to $10 \%$. No atrophy has occurred in our series, neither has any infection.

A possible disadvantage of jet therapy is a lateral tearing of the skin if the column of fluid strikes the skin at an angle. Care was taken to ensure the correct positioning of the gun, and no tears were seen.

Bleeding or oozing from the injection site is commoner in jet therapy than conventional methods, but is easily controlled by firm pressure for a few minutes or through a dressing left in place for two hours. On one occasion a branch of the left temporal artery was damaged and arterial bleeding occurred. This was easily controlled by firm pressure. No systemic reactions were observed.

\section{Summary}

The development of high-pressure jet injectors is described. One of the most recent is the Porton needleless injector. This injector has many advantages over conventional needles and syringes-freedom from pain, speed, no sterilizing of equipment between cases, and control over the speed, volume, and depth of injection.

Its use in the administration of intralesional steroid therapy in dermatological conditions is described. The diseases treated included alopecia (areata, totalis, and universalis), psoriasis, pustular psoriasis, chronic discoid lupus erythematosus, and granuloma annulare.
We wish to thank Dr. H. M. Darlow, Mr. G. H. Clement, and Mr. F. W. R. Penney, of the Microbiological Research Establishment, Porton, Wiltshire, for all their help throughout the time we have been using the injector, without which this work would have been impossible.

\section{REFERENCES}

Brit. med. F., 1963, 1, 767.

Gerard, A. G. (1960). Arch. Derm., 81, 535.

Goldman, L. (1962). 7. Amer. med. Ass., 182, 613.

Gombiner, A., and Malkinson, F. D. (1961). Arch. Derm., 83, 1004.

Hingson, R. A., and Figge, F. H. J. (1952). Curr. Res. Anaesth., 31, 361. Hirsh, H. L. Welch, H., Milloff, B., and Katz, S. (1948). F. Lab. clin. Med., 33, 805.

Hughes, J. G., Jordan, R. G., and Hill, F. S. (1949). Sth. med. f. (Bgham, Ala.), 42, 296.

James, A. P. R. (1960). F. invest. Derm., 34, 175.

(1961). Arch. Derm., 83, 661.

Krantz, A. (1960). Münch. med. W schr., 42, 2034.

Larrick, L. E., and Thompson, R. G. (1949). ' J. invest. Derm., 13, 361.

Margetis, P. M., Quarantillo, E. P., and Lindberg, R. B. (1958). U.S. armed Forces med. $7 ., 9,625$.

Orentreich, N., Sturm, H. M., Weidman, A. I., and Pelzig, A. (1960). Arch. Derm., 82, 894.

Perkin, F. S., Todd, G. M., Brown, T. M., and Abbott, H. L. (1950). Proc. Amer. diabetic Ass., 10, 185 .

Preston, R H., Goldman, L., and Thompson, R. G. (1951). Arch. Derm. Syph. (Chic.), 64, 327.

Readett, M. D. (1961). Brit. F. Derm., 73, 107.

Rebello, D. J. A. (1962). Ibid., 74, 358

Rowell, N. R. (1962). Brit. Ұ.' Derm., 74, 354.

Smith, J. F. Ferguson (1962). Ibid., 74, 350 .

Stephens, R. R., and Kramer, I. R. H. (1964). Paper presented at 84th Annual Conference of British Dental Association, London, p. 28.

Towle, R. L. (1960). Publ. Hlth Rep. (Wash.), 75, 471.

Warren, J., Ziherl, F. A., Kish, A. W., and Ziherl, L. A. (1955). F. Amer. med. Ass., 157, 633 .

Weidman, A. I. (1963). Curr. ther. Res., 5, 7.

Ziff, M., Contreras, V., and Schmid, F. R. (1956). Ann. rheum. Dis., 15, 227

\section{Glasgow Conference on Gastro-enterology}

[From a SPECIAL CoRrespondent]

A conference on gastro-enterology, organized by the Glasgow Postgraduate Medical Board, was held in the Royal College of Physicians and Surgeons of Glasgow on 1-3 December.

\section{Small Intestine Absorption}

The session on small intestinal absorption was opened by Dr. C. C. Booth (London), who reviewed mechanisms of intestinal absorption. These were classified as active transport, passive diffusion, facilitated diffusion, and pinocytosis. Sugars, fatty acids, minerals, electrolytes, and vitamin $B_{12}$ were absorbed by active transport which enabled these substances to be absorbed against an electro-chemical gradient. Watersoluble substances, such as vitamin-B complex, and lipid-soluble substances, such as barbiturates, were absorbed by passive diffusion where the rate of absorption was proportional to the concentration. Another possible method of absorption, facilitated diffusion, had some characteristics similar to both passive diffusion and active transport, and it was possible that folic acid and xylose might be absorbed by this mechanism. The last method of absorption, pinocytosis, whereby material was engulfed by the mucosal cell, might be more active in the lower part of the small intestine and might involve certain types of protein, fat, and vitamin $\mathbf{B}_{12}$
The electron microscopy of the mucosal cells of the small intestine was described by Professor G. M. WyBurN (Glasgow). He said there were approximately 1,000 microvilli to each mucosal cell, and each microvillus had a definite structure. The plasma membrane, which was not static but changing continually and being incorporated into the cell, contained adenosine triphosphate and enzymes, so that digestion and absorption were common in some respects.

\section{Cellular Activity}

Dr. B. Creamer (London) related histology of the small intestine to the dynamics of absorption. He said that active cell division took place in the crypts of the mucosa, and cells were continually displaced from there towards the tips of the villi. The turnover of cells in man was estimated to be two days. If cell division was arrested, migration ceased and the villi disappeared. Dr. Creamer described a spectrum change in the architecture of the villi ranging from normal to flat which he related to cellular activity. These changes were non-specific and could be primary or secondary to other conditions such as ulcerative colitis.

Dr. W. C. WATsoN (Glasgow) reviewed fat absorption and steatorrhoea. Steatorrhoea could arise in three situations; in the lumen of the intestine because of diminished area, jaundice, pancreatic deficiency, and shortcircuit procedures; in the mucosa because of impaired membrane transfer or esterification ; and outside the mucosa because of lymphatic obstruction.

\section{Drug Toxicity and the Liver}

Dr. G. P. Lewis (Glasgow) discussed physiological concepts in relation to drug toxicity. He said that the segmental pattern of acute toxicity suggested that the extent of liver damage depended on the state of the liver blood-flow. The pathological aspects of drug-induced liver damage were demonstrated by Dr. R. S. Patrick (Glasgow). This could be classified in three broad groups. The first group, which showed liver necrosis, was due to the direct action of a hepatotoxin, e.g., chloroform, to which everyone was susceptible. In the second group there was cholestasis due to the direct action of a drug, e.g., testosterone, to which most people were susceptible. In the third group there was a picture not unlike viral hepatitis with necrosis and cholestasis. This was caùsed by drug sensitivity and only a few patients were susceptible.

Dr. R. S. Williams (Southampton) discussed changes in liver-function tests. The effect which a drug had on the liver function would depend on the genetic composition of the patient, the age, the presence of coexist- 